\title{
EVALUASI PROGRAM KERJA PELAKSANAAN RENSTRA SMK NEGERI 56 JAKARTA, JL. RAYA PLUIT TIMUR, PLUIT, PENJARINGAN JAKARTA UTARA PERIODE 2011-2015
}

\author{
Maria Damiana Riyani*
}

Abstract: This research is subject to be know performing works program evaluation resntra Vocational Middle School 56 Jakarta. Method observationaling to utilize descriptive method with model CIPP (Contex, Input, Process, and Product) one that developed by Stufflebeam \& Shinkfield. Evaluation programs to constitute one of object type of evaluation research (Evaluation Research). mendasar's orientation on all evaluation research is benefit. Strategic plan performing program Vocational Middle School 56 needs to mark sense repairs all lini, it can be drawn as follows: 1) Pemesinan's forte Programs, 2) vehicle forte Programs Demulcent (Otomotif), 3) Installation forte Programs Electrify, 4) Pictured forte Programs Buildings, 5) Multi's forte Programs Medias, and 6) Mechatronicses forte program. Suggested observational result to restra's executor to get follows up many findings in particular that concerns to program restra, and performs program repair so activity process program restra to become more effective.

Keywords: startegic plan, works program evaluation

\section{PENDAHULUAN}

Pendidikan merupakan hal yang sangat penting dan merupakan ujung tombak bagi kelangsungan hidup masa depan seseorang. Terkait hal tersebut, Ki Hajar Dewantara (Bapak Pendidikan Nasional Indonesia) menjelaskan tentang arti penting dari pendidikan, yakni sebagai berikut "Pendidikan umumnya berarti daya upaya untuk memajukan budipekerti (karakter, kekuatan bathin), pikiran (intellect) dan jasmani anak-anak selaras dengan alam dan masyarakatnya". Begitu pentingnya pendidikan menjadikan sebuah Negara memiliki tanggungjawab berkaitan dengan wajibnya warga Negara mendapatkan pendidikan, seperti yang tercantum pada Bab 13 pasal 31 ayat 1 UUD 1945 yang berbunyi: (1) Tiap-tiap warga Negara berhak mendapat pengajaran.

Pendidikan Sekolah Menengah Kejuruan yang di kelola dengan profesional adalah merupakan suatu jawaban dalam memenuhi kebutuhan tersebut. Oleh karena itu perlu merekonstruksi, mereposisi dan perencanaan ulang untuk mempersiapkan kinerja sumber daya manusia yang dapat memenangkan persaingan dengan negara-negar lain.

\footnotetext{
* Guru Bidang Studi Bahasa Inggris SMK Negeri Dekai Kabupaten Yahukimo Papua
} 
Sekolah Menengah Kejuruan Negeri (SMKN) 56 Jakarta, yang saat ini berada pada posisi SMK RSBI (Sekolah Menengah Kejuruan Rancangan Sekolah Bertaraf Internasional), memiliki sasaran pengembangan ke arah menuju SMK SBI (Sekolah Menengah Kejuruan Sekolah Bertaraf Internasional). Oleh karena itu rencana anggaran, desain perkembangan dijabarkan melalui Pengembangan Sekolah Berwawasan Bisnis.

Sekolah Menengah Kejuruan Negeri (SMKN) 56 Jakarta, memiliki Kompetensi Keahlian Teknik Gambar Bangunan, Teknik Instalasi Tenaga Listrik, Teknik Mekatronika, Teknik Pemesinan, Teknik Kendaraan Ringan dan Multi Media, siap menghasilkan tamatan yang berkualitas. Pelaksanaan perencanaan strategis selalu berupaya merumuskan langkah kerja yang efektif dan efisien, sehingga keputusan yang diambil oleh lembaga pendidikan dapat menjadi hal yang terbaik. Selanjutnya penyusunan perencanaan strategis lebih kepada implikasi dari suatu keputusan. Sistem pengambilan keputuan pada tingkat lembaga pendidikan yaitu mengumpulkan informasi secara luas dengan memfasilitasi komunikasi dan partisipasi, mengakomodasi dari kepentingan dan perbedaan nilai serta adanya evaluasi dalam pelaksanaan program kerja renstra.

\section{Evaluasi}

Rogers (2005:2) memberikan pengertian, "evaluation is the process of systematically collecting and analysinginformation in order to form value judgements based on firm evidence.". Evaluasi adalah proses sistematis mengumpulkan dan menganalisis informasi dalam rangka untuk membentuk penilaian nilai berdasarkan bukti yang kuat. Penilaian ini melihat sejauh mana pencapainnya sehingga dilakukan pengambilan suuatu keputusan. Dalam hal ini dilakukan pengumpulan data yang tepat sebagai dasar penilaian.

Mertens (2004:17) memberikan pengertian evaluasi, "evaluation is the systematic investigation of the merit or worth of anobject for the purpose of reducing uncertainty in decision making aboutthat object." Program adalah sesuatu yang coba dilakukan seseorang atau lembaga dengan harapan akan mendatangkan hasil atau pengaruh. Program dapat didefinisikan sebagai unit kegiatan yang merupakan implementasi dari suatu kebijakan, berlangsung dalam proses yang berkesinambungan, dan terjadi dalam suatu organisasi yang melibatkan sekelompok orang. Knox (2002:201) mengatakan, Program is connected with all other aspects (goals, context, participants, needs, staff, materials, outcomes), it is essential that evaluation of the program focus on the issues that are most important to stakeholders and have an effective and manageable design that will be implemented and will attract necessary resources and cooperation. Program terhubung dengan semua aspek lain (tujuan, konteks, peserta, kebutuhan, staf, materi, hasil atau dampak), hal ini sangat penting dalam evaluasi program yang fokus pada isu-isu strategis untukpemangku kepentingan dan memiliki desain yang efektif membuat yang lain tertarik untuk bekerjasama. 


\section{METODE}

Penelitian evaluasi program ini menggunakan metode deskriptif dengan model CIPP (Contex, Input, Process, dan Product) yang dikembangkan oleh Stufflebeam \&Shinkfield.Evaluasi program merupakan salah satu jenis objek dari penelitian evaluasi (Evaluation Research). Orientasi mendasar pada semua penelitian evaluasi adalah manfaat.Manfaat dalam hal ini adalah menyediakan informasi untuk mengambil keputusan dalam kerangka meningkatkan (to improve) layanan. Program Renstra di SMKN 56 Jakarta Jl. Raya Pluit Timur, Pluit, Penjaringan Jakarta Utara. Pelaksanaan dan evaluasi Renstra SMK NEGERI 56 Pluit Jakarta Utara Periode 2011 - 2015.

\section{HASIL DAN PEMBAHASAN}

1. Apa yang menjadi isu utama dan langkah perumusan serta penyusunan Renstra SMK Negeri 56 Pluit Jakarta Utara Periode 2011 - 2015 ?

Dasar pentingnya kebijakan pembuatan renstra di SMK 56, renstra sendiri sebetulnya dibuat dari hasil evaluasi sekolah itu sendiri dengan melihat pada delapan standar pendidikan : Standar kompetensi lulusan, standar isi, standar proses, standar pendidikan dan tenaga kependidikan, standar sarana dan prasarana, standar pengelolaan, standar pembiayaan pendidikan dan standar penilaian pendidikan dari delapan standar yang ditetapkan oleh pemerintah itulah SMK 56 mengetahui posisinya, keunggulannya dibidang apa dan kelemahannya dibidang apa. Setelah diketahui kelebihan dan kelemahannya SMK 56 melakukan pengembangan, bagian yang sudah baik SMK 56 pertahankan bahkan harus tingkatkan yang masih lemah kita naikkan kualitasnya agar dapat menjadi lebih baik dan memenuhi syarat, sehingga dari delapan standar pendidikan yang ditetapkan oleh pemerintah SMK 56 dapat memenuhi standar bahkan akan lebih baik lagi jika dapat melampaui standar-standar yang ditetapkan oleh pemerintah.

Berkaitan dengan isu utama SMK 56 selalu mengikuti perkembangan yang terjadi atau terbaru jadi ketika presiden memberikan statement untuk revitalisasi SMK khususnya di bidang sumber daya manusia agar kita punya daya saing di tingkat internasional di pasar kerja maka sekolah tentunya melalui delapan standar pendidikan langsung melakukan perbaikan dan fokus pada tujuan pemerintah, sehingga dapat selaras dan mendukung semua program pemerintah. Semua itu tentunya kita bicarakan melalui rapat kerja sekolah di SMK 56, biasanya rapat diawali dengan hasil evaluasi dini sekolah disamping itu para guru juga melihat hasil monitoring evaluasi yang dilakukan oleh dinas pendidikan dari hasil tersebut diambil poin-poinnya, bidang apa saja yang perlu direkomendasikan untuk dikeluarkan atau diganti.

SMK 56 selalu melakukan yang terbaik agar dapat menghasilkan sumber daya manusia yang betul-betul bisa memenuhi kebutuhan pasar kerja jadi menggunakan prinsip demandrever, pengertian demandrever itu kebutuhan pasar kerja SMK 56 mempersiapkan kalau demansuply itu walaupun masyarakat tidak 
perlu kita terus produksi akan tetapi disini SMK 56 menggunakan demandrever jadi disini kita mencetak sumber daya manusia berdasarkan kebutuhan pasar kerja maka akan selalu terinovasi untuk membuka kompetensi baru dan pada tahun ini kita SMK 56 mempunyai kesempatan untuk membuka dua kompetensi keahlian tambahan yaitu teknik kompeter jaringan dan produksi industri

Langkah rumusan dan penyusunan rentra di SMK 56 dilakukan dengan pembentukan kepanitiaan yang ditetapkan melalui rapat kerja sekolah dari kepanitiaan tersebut dibentuklah bidang-bidang penanggung jawab diantaranya : bidang standar kompetensi lulusan, bidang standar isi, bidang standar pendidikan, bidang standar prasarana dan bidang standar pembiayaan, setiap bidang tersebut nantinya akan menyusun perencanaan sesuai dengan program kerja dan hasil evaluasi renstra dan pada akhir sesi rapat kerja masing-masing komisi atau bidang mempresentasikan hasil musyawarahnya di tiap bidang kemudian setelah semuanya menjelaskan barulah akan dikerjakan secara general secara bersama-sama kemudian nanti dirumuskan menjadi evaluasi renstra.

2. Bagaimana kesesuaian isi dokumen Renstra SMK Negeri 56 Pluit Jakarta Utara Periode 2011 - 2015 dengan visi misinya yang sudah ditetapkan?

Menyusun renstra agar selaras dengan visi SMK 56 dengan cara melibatkan seluruh unsur yang ada pertama SMK 56 melibatkan unsur struktur organisasi sekolah mulai dari wakil kepala sekolah bidang kurikulum, bidang hubungan industri dan masyarakat, bidang kesiswaan, bidang sarana dan prasarana kemudian dibantu oleh kepala kompetensi keahlian. Kepala kompetensi keahlian merupakan kepanjangan tangan dari kepala sekolah atau disebut kepala dijurusan, masingmasing dari kepala jurusan sama dalam melihat hasil evaluasi kinerja sekolah. Dengan cara melihat rencana program sekolah sebelumnya dan rencana program sekolah tahun berikutnya, semua itu nanti disusun secara bersama-sama sehingga dapat menjadi sebuah program unggulan sehingga dapat mewujudkan dari visi SMK 56 Jakarta.

Menyusun renstra agar selaras dengan misi SMK 56, misi adalah turunan dari visi, visi lebih pada capaian jangka panjang akan tetapi untuk dapat diwujudkannya harus diturunkan menjadi misi sekolah. Misi itu bagaimana membuat programnya agar dapat mewujudkan impian dari sekolah apakah bisa dicapai.jadi visi dalam rentra harus di breakdown menjadi misi, misi lembaga di breakdown menjadi masing-masing kompetensi keahlian, kemudian dari masingmasing misi tersebut baik itu kelembagaan atau kompetensi keahlian di breakdown menjadi kegiatan nyata yang bisa dilaksanakan dan semua itu direncanakan dan dimonitor nantinya melalui sebuah program.

Pelaksanaan renstra di SMK 56 hingga saat ini selalu berjalan dengan baik akan tetapi didalam perjalanan itu selalu ada sedikit perubahan, hal tersebut terjadi karena terkadang ada program mendadak yang harus dilakukan di tengah-tengah kegiatan yang tidak direncanakan sebelumnya akan tetapi harus dilaksanakan hal seperti itulah yang nantinya akan menjadi sebuah rekomendasi ketika di evaluasi, 
ternyata ada kegiatan-kegiatan yang tidak ada didalam rencana program tapi itu program tambahan yang harus dilaksanakan. Program tersebut merupakan sisipan atau terkadang sifatnya dadakan akan tetapi SMK 56 tetap menangani hal tersebut sehingga dapat menjadi sebuah catatan bagi SMK 56, khususnya agar terdapat pengagendaan pada renstra berikutnya agar terencana terencana lebih baik lagi sehingga hal seperti itu dapat terminimalisir untuk terjadi.

Penigkatan hubungan SMK 56 dengan perusahaan terus SMK 56 jalankan dengan membuat memorandum of understanding jika industri tertentu sudah merasa nyaman dan puas dengan MOU yang telah dijalankan, SMK 56 tingkatkan statusnya menjadi kerjasama bentuk nyata dari kerjasama ini di SMK 56 ada kardus robotik. Kardus robotik adalah robot yang dibuat oleh industri yang melibatkan para peserta didik dari SMK 56 dan pelaksanaannya langsung ditempatkan disekolah. Industri juga melakukan usaha perbaikan mobil yang dalam proses pelaksanaannya melibatkan para peserta didik di SMK 56 Jakarta.

Adanya kesempatan praktek ketika sekolah membuat peserta didik lulusan SMK 56 menjadi memiliki kualitas. Para alumni SMK 56 membentuk perkumpulan ikatan alumni SMK 56 melalui setiap kegiatan alumni tersebut SMK 56 dapat mengetahui karir dari lulusannya, adanya yang menjadi pejabat diperusahaan swasta bahkan adanya yang menjadi pemilik perusahaan owner, ada lulusan yang mendirikan dua rumah sakit, bahkan lulusan yang berhasil mendirikan 3 perguruan tinggi swasta, dan lulusan kebanyakan mendirikan perusahaan sehingga dari perusahaan tersebut para alumni SMK 56 melalukan perekrutan terhadap adik-adik kelasnya untuk menjadi karyawan diperusahaannya, dengan adanya kesempatan ini membuat para lulusan SMK 56 tidak ada yang menjadi pengangguran semua terrekrut dengan baik di perusahaan-perusahaan, bahkan ada beberapa jurusan tertentu yang lulusannya sudah direkrut oleh perusahaan milik alumni ketika hasil ujian atau kelulusannya belum diumumkan akan tetapi sudah diterima diperusahaan tersebut.

3. Bagaimana pelaksanaan dan evaluasi Renstra SMK Negeri 56 Pluit Jakarta Utara Periode 2011 - 2015?

Evaluasi yang dilakukan oleh SMK 56 untuk mengetahui tingkat keberhasilan renstra yaitu dengan melakukan evaluasi terhadap setiap setiap agenda yang ada pada renstra sebelumnya, evalusi di SMK 56 berpatokan pada instrument EDS (evaluasi diri sekolah) dimana setiap evaluasi itu sudah ada standar indikator-indikatornya atau menggunakan instrument yang ada di monitoring evaluasi yang didalamnya terdapat pula standar-standar yang menilai apakah kinerja SMK 56 telah memenuhi target capaian dari renstra atau bahkan melebihi target. Melihat pada indikator-indikator tersebut SMK 56 dapat mengetahui posisinya telah mencapai sejauh mana dan itu dapat tergambar dari sarang laba-laba hasil evaluasi diri sekolah.

Periode evaluasi yang dilaksanakan di SMK 56 melalui beberapa jenis evaluasi pertama evaluasi secara langsung atau direct evaluation pelaksanaanya 
dilakukan secara diam-diam dengan cara mengapati individu yang akan disupervisi, akan tetapi yang sudah terprogramkan itu supervise semester, dalam satu semester minimal SMK 56 melakukan supervise sebanyak dua kali dilaksanakan pada pertengahan semester dan diakhir semester, jadi dalam satu tahun supervisi yang sudah terencana akan dilakaukan sebanyak empat kali.

Kegiatan audit atau sipervisi memang terus berjalan di SMK 56 dan sampai saat ini kegiatan tersebut berjalan dengan baik contoh dari supervisi di SMK 56 yaitu ketika para guru mengajar maka tim dari supervisor melakukan penilaian. Supervisor ini kita bentuk atas keputusan kepala sekolah lalu ditunjuklah tim dari supervisor ini dengan dikeluarkannya surat keputusan sebagai supervisor didalam surat keputusan itu pula disebutkan siapa saja yang akan disupervisi. Hasil dari supervisi akan di kembaikan kepada guru yang disupervisi, sekolah melakukan diskusi dengan individu yang bersangkutan dan mencari solusinya jika ada beberapa kelemahan atau kesalahan yang dilakukan oleh guru tersebut, hal tersebut dilakukan untuk meningkatkan kualitas para guru di SMK 56 menjadi lebih bermutu dan professional.

SMK 56 membuat menejemen sekolah dengan pendekatan berbasis bisnis. Pendekatan seperti ini selalu SMK 56 lakukan, didalam proses pelaksanaannya, pengawasan pelekat yang bertanggung jawab ketika para guru dan tim menjalankan program kepala sekolah dibantu oleh jajarannya yang telah dipilih secara silang melakukan audit di SMK 56 disebut dengan istilah audit internal. Audit internal ini memiliki aturan bahwa yang melakukan audit bukan orang yang ada kelopok tersebut. Contohnya mengecek kurikulum, hal itu dilakukan oleh orang-orang rubit atau sebaliknya orang-orang rubit pula akan di audit oleh orang-orang sarana jadi accountable mesti berjalan dengan adanya pengawasan pengawasan pelekat.

Meningkatkan minat menjadi pengusaha di SMK 56. Menurut kepala sekolah SMK 56 menjadi wirausahaan itu pada prinsipnya adalah bagaimana para peserta didik diajarkan untuk memiliki rasa percaya diri yang tinggi, menumbuhkan sifat gigih, ulet dalam menjalaninya, tidak gampang untuk menyerah atau putus asa, dan dapat menciptakan peluang atau pandai memanfaatkan kesempatan yang terpenting bagi para peserta didik ini yaitu mampu untuk mengimplementasikan apa yang menjadi kemampuannya menjadi hard kompeten jadi peserta didik di SMK 56 diajak untuk dapat berkarya dari ide-idenya baik itu secara langsung maupun secara tidak langsung. Maksud secara langsung itu peserta didik dapat mempraktekkan secara langsung atau terjun dalam bidangnya.Sedangkan maksud dari tidak langsung yaitu melui sebuah pengamatan hasil pelatihan-pelatihan yang dilakukan oleh masyarakat terkait bidang-bidang bidang keahlian yang dipilih oleh peserta didik.

Meningkatkan pembelajaran dengan cara monotrek artinya terjadwal setiap saat dan termonitor pelaksanaannya di dukung oleh guru piket dalam pelaksanaannya menjelang akhir semester, baik itu ujian nasional ataupun ujian sekolah sebelum itu SMK 56 melaksanakan program penguatan-penguatan kepada 
peserta didik melalui kegiatan pengarahan dan tes ujian hal tersebut SMK 56 lakukan secara intens terprogram dan berkesinambungan.

Cara SMK 56 melihat keberhasilan peserta didiknya dengan mengukur dua aspek, yaitu aspek akademik dan non akademik.Aspek akademik dapat dilihat dari hasil ujian nasional dan dua hasil ujian lainnya yang menjadi ciri khas dari sekolah kejuruan yaitu ujian kempetensi keahlian dan ujian teori kejuruan ditambah lagi dengan ujian umum sebagaimana standar ujian yang ada di sekolah. Kemudian aspek non akademik hal ini dapat diraih melalui berbagai kegiatan yang ada didalam ekstrakulikuler di SMK 56, contohnya adalah lomba kompetensi siswa bidang mikrotonika yang kebetulan tahun 2017 ini SMK 56 mendapatkan kesempatan mewakili Indonesia untuk berangkat ke Abu Dhabi dalam perlombaan word skill competition. SMK 56 mengirimkan dua peserta didik mikrotonika yang akan mengikuti kejuaran di word skill competation sebab pada bulan januari lalu SMK 56 berhasil mengalahkan juara Asian skill yakni yayasan Tadius Semarang, kemudian di tahun yang sama dua peserta didik dari SMK 56 berhasil meraih mendali emas dalam lomba mikrotonika di Solo, dan sudah dua tahun berturutturut SMK 56 meraih medali emas.

Prestasi lain yang diperoleh peserta didik di SMK 56 meliputi tujuh kompetensi keahlian. Dalam bidang olahraga SMK 56 juga banyak meraih emas diantaranya olahraga futsal, tekwondo dan pecak silat, dan lain-lain. Banyaknya prestasi yang didapatkan oleh peserta didik di SMK 56 merupaka hasil pengembangan didalam evaluasi renstra yang dinaungi oleh kegiatan kesiswaan sehingga peserta didik dapat menjalankan kegiatan sesuai dengan rencana pada renstra, SMK 56 memfokuskan agar peserta didik agar dapat meraih prestasi dan menjadi individu berhasil didalam bidang akademik maupun non akademik.

\section{PENUTUP}

\section{Kesimpulan}

Berdasarkan pembahasan pada bab sebelumnya, diperoleh hasil tentang kekuatan dan kelemahan internal dan ekternal, isu utama dan langkah perumusan serta penyusunan renstra, kesesuaian isi dokumen renstra dengan visi, misinya yang sudah ditetapkan, pelaksanaan dan evaluasi renstra SMK Negeri 56 Pluit Jakarta Utara Periode 2011 - 2015. Maka dapat disimpulkan sebagai berikut: 1) Kekuatan dan kelemahan internal dan ekternal renstra dapat disimpulkan kekuatan SMK 56 sangat baik, karena memiliki SDM yang bermutu, sarana dan prasarana yang lengkap, modal sosial yang baik serta terjalinya kerjasama yang baik dengan swasta dan pemerintah dalam menyerap lulusan. Adapun kelemahannya, yaitu terus berkembangnya teknologi dan informasi sehingga sekolah harus terus memperbaharui materi dan metode pembelajaran serta alat-alat praktik mesin. 2) Isu utama dan langkah perumusan serta penyusunan renstra, isu utama dengan melihat pada kebutuhan pasar kerja dengan begitu sekolah akan terus terinovasi untuk membuka kompetensi baru. Langkah rumusan dan penyusunan renstra dilakukan dengan membentuk kepanitiaan yang ditetapkan melalui rapat kerja sekolah dari 
kepanitiaan tersebut dibentuklah bidang-bidang penanggung jawab diantaranya : bidang standar kompetensi lulusan, bidang standar isi, bidang standar pendidikan, bidang standar prasarana dan bidang standar pembiayaan, setiap bidang tersebut nantinya akan menyusun perencanaan sesuai dengan program kerja serta hasil dari evaluasi renstra sebelumnya dan di akhir rapat kerja masing-masing bidang mempresentasikan hasil temuannya lalu dirumuskan menjadi renstra selanjutnya. 3) Kesesuaian isi dokumen renstra dengan visi, misinya yang sudah ditetapkan, program dibuat dengan melihat hasil evaluasi program sebelumnya dengan melibatkan seluruh unsur yang ada disekolah yaitu kepala sekolah, wakil kepala sekolah bidang kurikulum, bidang hubungan industri dan masyarakat, bidang kesiswaan, bidang sarana dan prasarana dan kepala kompetensi keahlian. Hasil rempug tersebut menjadi program unggulan yang dapat mewujudkan visi dan misi dari SMK 56 Jakarta. 4) Pelaksanaan dan evaluasi renstra, evaluasi dilakukan dengan melihat pada renstra sebelumnya dengan berpatokan pada instrument EDS (evaluasi diri sekolah) dimana setiap evaluasi sudah ada standar indikatornya yang tergambar pada sarang laba-laba hasil evaluasi. Periode evaluasi yang terencana dilakukan empat kali dalam setahun dilakukan pada pertengahan semester dan akhir semester adapun jenis evaluasinya secara langsung atau direct evaluation dan supervisi semester. Supervisor di bentuk atas keputusan kepala sekolah dengan mengeluarkan surat keputusan sebagai supervisor hasil dari supervisi tersebut di kembaikan kepada guru yang disupervisi, sekolah melakukan perbaikan dengan guru yang bersangkutan dan mencari solusinya agar guru tersebut menjadi lebih bermutu dan professional.

\section{Rekomendasi}

Guru merupakan ujung tombak keberhasilan pendidikan serta dianggap sebagai orang yang berperan penting dalam pencapaian tujuan pendidikan yang merupakan pencerminan mutu pendidikan. Keberadaan guru dalam melaksanakan tugas dan kewajiban tidak lepas dari pengaruh internal ataupun faktor eksternal yang membawa dampak pada perubahan kinerja guru.

Kinerja guru merupakan kemampuan yang ditunjukan guru dalam melaksanakan tugas nya. Kinerja dapat dikatakan baik dan memuaskan jika tujuan yang dicapai sesuai dengan standar yang telah ditetapkan. Dalam meraih mutu pendidikan yang baik sangat dipengaruhi oleh kinerja guru dalam melaksanakan tugas nya sehingga kinerja guru menjadi tuntutan penting untuk mencapai keberhasilan pendidikan.

Sebagaimana yang telah di uraikan di atas hasil evaluasi kinerja guru di SMK NEGERI 56 JAKARTA, terdapat beberapa hambatan yang dapat terhambatnya kinerja guru dalam pelaksanaan tugasnya maka perlu kiranya dilakukan tindakan korektif untuk meningkatkan kinerja guru. Tindakan korektif yang bisa dilakukan yaitu: 1) Kepala sekolah melakukan monitoring kepada guru secara berkala. Dapat memberikan supervisi dalam membantu guru mengelola jam pembelajaran dikelas. 
Guru juga dapat membuat RPP yang berbeda dengan metode yang berbeda sesuai dengan kondisi kelas nya. Kepala sekolah dapat memberikan dorongan kepada guru untuk membebaskan metode yang dipakai dalam mengelola kelas putra-putri. Karena suasana dan kondisi kelas yang berbeda seharusnya menggunakan metode yang berbeda agar peserta didik dapat menerima materi pelajaran dengan baik. 2) Kepala Sekolah, guru, karyawan, wali murid juga masyarakat sudah seharusnya bekerja sama dalam pengembangan pendidikan. Maka, keterlibatan semua pihak juga membantu dalam peningkatan kinerja guru. Wali murid dapat berkomunikasi dengan baik dengan guru tentang perkembangan peserta didik di sekolah. Komunikasi antara steakholder di sekolah merupakan salah satu cara peningkatan mutu pendidikan, sekolah dapat mengkomunikasikan kegiatan, program serta pendanaan terkait dengan pembelajaran peserta didik. sehingga setelah peserta didik lulus dapat memperoleh nilai juga pribadi yang baik.3) Kedisiplinan guru yang kurang akan mengakibatkan terganggunya proses belajar mengajar karena ketidakefektifan jam pembelajaran. Maka, kepala sekolah harus menindak tegas untuk mengurangi hal tersebut. Dengan adanya absen guru setiap harinya, apabila terlambat atau tidak datang pada saat proses pembelajaran tidak berasalan yang jelas. Maka kepala sekolah atau pimpinan yang berwenang dapat memberikan teguran atau pemberhentian terhadap guru yang bersangkutan. Selain itu, perlu nya motivasi guru dalam bekerja di sekolah juga diperlukan untuk meningkatkan kinerja guru. Guru yang rajin, guru yang di nilai baik dalam menjalankan tugas nya seharusnya di berikan apresiasi. Hal tersebut di maksudkan untuk memberikan semangat guru dalam melakukan tugasnya di sekolah dan memberikan yang terbaik untuk perkembangan peserta didik. 4) Proses perekrutan guru yang harus sesuai dengan standar. Guru yang berkompeten dalam bidangnya salah satunya, yaitu perekrutan guru dilakukan dengan menggunakan tes yang sesuai.

Dalam upaya peningkatan mutu pendidikan dapat dilakukan beberapa hal yang dapat memperngaruhi kinerja guru sehingga lebih maksimal diantaranya sebagai berikut: 1) Melaksanakan program MGMP (Musyawarah Guru mata Pelajaran). MGMP dalah forum kegiatan profesional guru mata pelajaran sejenis. Dengan MGMP ini diharapkan guru dapat meningkatkan metode pembelajaran, teknis edukatif tentang IPTEK yang bisa di gunakan dalam pembelajaran di kelas, berbagi informasi, dan meningkatkan profesionalisme guru. 2) Pemberdayaan guru yang ada di sekolah. Pemberdayaan guru dapat dilakukan dengan program pelatihan terintegrasi berbasis kompetensi. Hal ini dapat mendorong kinerja guru meningkat sehingga hasil pembelajaran oleh peserta didik juga baik. Pelatihan yang diperlukan adalah pelatihan yang disesuaikan dengan kebutuhan guru, yaitu pelatihan yang mengacu pada tuntutan kompetensi guru. Pelatihan ini dapat diselenggarakan mandiri oleh sekolah, atau program pemerintah. Guru harus menambah kompentensi mereka, menambah ilmu dan sumber pembelajaran yang akan berdampak pada peningkatan mutu pendidikan bagi peserta didik. 


\section{DAFTAR RUJUKAN}

Glyn Rogers and Linda Badham, Evaluation In Schools: Getting Started On Training AndImplementation. New York: Routledge, 2005

Donna M. Mertens, John A. McLaughlin. Research and evaluation methods in special education. California: Corwin Press, Inc. 2004

Alan B. Knox. Evaluation for continuing education: a comprehensive guide to success. Denver: John Wiley \& Sons, Inc, 2002

Daniel L Stuffebeam and Anthony J. Shinkfield, Teacher evaluation: Guide to Effective Practice. Boston: Kluwer Academic Publishers, 1995

Daniel L. Stufflebeam, Evaluation Models, Viewpoints on Educational and Human Services Evaluation Second Edition. Boston: Kluwer Academic Publishers, 2001

Daniel Wallach et.al., Working with Dynamic Crop Models Evaluation, Analysis, Parameterization, and Applications. Amsterdam: Elsevier B.V. 2006

David Royse et al., Program Evaluation. Belmont: Wadsworth Cengage Learning, 2010

Lexy J. Moleong, Metode Penelitian Kualitatif (Bandung Remaja Rosdakanya. 2002

Nasution, Metode Penelitian Naturalsitik Kualitatif cetakan ulang ketiga Bandung: PT. Tarsito, 2003

Peter H. Rossi et al, Evaluation A Systematic Approach. California, SAGE Publications, Inc, 1999

Rachmat, Manajemen Strategik. Bandung, Pustaka Setia, 2013

Richard Kiely and Pauline Rea-Dickins, Program Evaluation in Language Education. New York: Palgrave Macmillan, 2005

Siri N. Espy, Handbook of strategic planning for nonprofit organizations. New York: Praeger Publishers, 1986

SMKN 56 Jakarta, Rencana Strategis 2011-2015, tidak diterbitkan 